\title{
RNA biologist Joan Steitz awarded the 2018 Lasker Koshland Special Achievement prize
}

$T_{\text {h }}$ he Albert and Mary Lasker Foundation has selected Joan Steitz as the winner of the 2018 Lasker Koshland Special Achievement Award in Medical Science for her leading role in the field of RNA processing and for promoting the advancement of women in science.

\section{A giant in RNA biology}

Joan Steitz (Figure 1) has made numerous seminal contributions to our understanding of RNA biology. As a postdoctoral researcher, Steitz was the first to describe the translation initiation sites of prokaryotic RNA in 1969 (1). This discovery helped her secure her own lab at Yale University, where she continues an active research program to this day. As an independent investigator, she turned her attention to eukaryotic cells, focusing on why eukaryotic cells produce an excess of RNA in the nucleus that is not found in cytoplasm in the form of mRNA.

In 1977, the Sharp and Roberts labs established that eukaryotic mRNA was spliced into a mature form that is exported to the cytoplasm for translation (2). This exciting discovery prompted Steitz to explore the fundamental mechanisms of the splicing process. During the previous year, she had set out to make antibodies against heterogeneous nuclear ribonucleoproteins (hnRNPs), which bind to newly transcribed RNA, but her efforts were unsuccessful due to strong conservation of hnRNPs between species. Taking a different approach in 1978, Steitz and Michael Lerner, an MD-PhD student in her lab, decided to look at autoantibodies from patients with systemic lupus erythematosus (3). Unexpectedly, these antibodies bound to small nuclear RNA molecules (snRNAs) associated with specific proteins, which they discovered exist in complexes of small nuclear ribonucleoprotein (snRNPs). Subsequent work in Steitz's lab suggested the intriguing possibility that these newly described snRNPs might participate in splicing (4).
Much was still uncertain in these days and shortly thereafter, to Steitz's chagrin, a news item published in Science dismissed the notion that snRNAs contribute to the splicing process (5). Undaunted, she continued her work on snRNPs and established the binding of the U1 snRNP complex selectively to splice sites on unprocessed mRNA (6). Steitz and her team subsequently detailed the involvement of several ribonucleoproteins in pre-mRNA splicing and the generation of the mature mRNA product

\section{A trailblazer for women in science}

Steitz's career began in an era when female scientists were still very much a rarity. Originally, she planned to attend medical school, believing a career in medicine was more attainable for women than pursuing scientific research. Thankfully, her talent for scientific inquiry was apparent to Joseph Gall, a mentor who entrusted her with a summer research project after she completed her undergraduate degree. Gall encour-

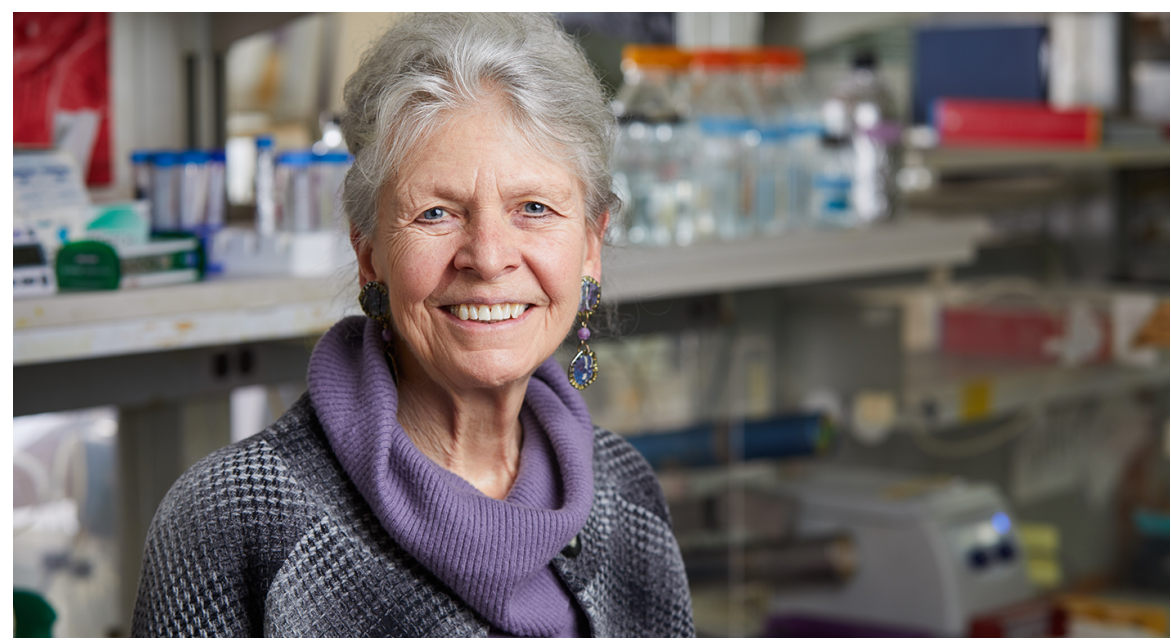

Figure 1. Joan Steitz, recipient of the 2018 Lasker Koshland Special Achievement Award. Image credit: Robert Lisak.

(7). Later, her lab discovered yet another unforeseen finding, showing that parts of introns can form small nucleolar RNAs (snoRNAs) that associate with ribosomal RNAs but are not protein coding (8). Cumulatively, this work was truly groundbreaking in that it established fundamentally new functions for RNA, independent of coding and ribozyme activities, and was the first indication that small noncoding RNAs were an essential tool that cells use to regulate biological processes. Steitz's work catapulted the RNA biology field forward with her unanticipated discoveries concerning small noncoding RNA. aged her to switch from medical school to the biochemistry and molecular biology program at Harvard University, making her the sole woman in her entering class. At Harvard, Steitz became the first female graduate student in the lab of famed scientist James Watson, during which time she studied mRNA translation using the bacteriophage model system. She continued these efforts in her postdoctoral studies at the University of Cambridge, training with Francis Crick, Sydney Brenner, and Mark Bretscher.

Steitz attributes her notable and perhaps unexpected success as a postdoc to having the freedom to take on a high-risk project. Steitz recently told the JCI, "The project was too challenging and too risky 
for my male postdoc peers to take on because if it didn't work they wouldn't have anything to show in two years, which was the postdoc time allotted if they wanted to go back to the States and get a job." Since she never expected to have her own lab, she was liberated to take on the project that would lead to the discovery of how ribosomes recognize the translation start site on an mRNA. She also credits her husband, Nobel laureate Tom Steitz, for being willing to split household and childcare duties (in a time many men did not) and for truly encouraging her academic pursuits.

When Joan Steitz was first offered a faculty position at Yale University, she had some reservations about whether she was up to the task. She confided in her former mentor James Watson, and she relayed to the JCI that, "he told me about when he started as a professor at Harvard and how he had the same sort of nightmares about whether he would be able to get up and give a lecture." Despite controversial statements made by Watson in later years, Steitz found him to be supportive in the course of her career. Reassured that her self-doubts were normal, she was ready to take on the challenge of establishing her own lab.

At Yale, Steitz worked in a department established by protein chemist Fred Richards, who had trained with Barbara Lowe at Harvard Medical School. Steitz notes that Richards was very egalitarian in his thinking and that he also had a nose for talent, bringing in multiple new faculty who would later become National Academy of Sciences members. This open and intellectually stimulating environment would prove fertile ground for academic success. Steitz was inducted into the National Academy of Sciences in 1983, and in 1986 she became an investigator of the Howard Hughes Medical Institute, a distinction that she still holds today.

\section{An advocate for the advancement of women}

Early in her career, Steitz was mindful that she was a role model for women in her lab and the department. Steitz was conscientious about ensuring that all of her students had independent research projects, a model which had sparked her own initial scientific success, and she especially encouraged female trainees.
Her foray into more active statesmanship would come much later in her career. In 2005, Steitz was asked to join a panel that would write a National Academy of Sciences report on the state of women in academic science (9). While working on this report, she learned about work in the field of psychology on unconscious bias and social identity threat. Through this lens, many of her own experiences through the years suddenly made sense. Steitz told the JCI, "I used to sit in meetings and be the only woman, and wonder why I didn't feel like I could say anything. That feeling has to do with social identity threat. I always try to tell groups of women scientists about this phenomenon because I think it's a major thing that continues to hold us back."

Spurred by a new understanding of gender dynamics in the scientific community, Steitz vowed that she would speak out at any opportunity given. She became one the founding board members of the Rosalind Franklin Society, a group dedicated to honoring and promoting women in science, and she accepted as many speaking engagements as she could.

We've come a long way since the days when Steitz was the only woman in her incoming graduate student class, but Steitz emphasizes that there is still so much left to be done. A recent survey by the National Science Foundation found that 55\% of $\mathrm{PhDs}$ in life sciences were earned by women (10) yet only $44 \%$ of newly hired assistant professor positions and about one-third of the total tenure-track positions are held by women (11). Such data point to several leaks in the pipeline of women progressing into senior positions in academic research. Steitz points to innovative programs that have been successful in improving retention of women, such as the Athena SWAN Charter in the United Kingdom, which holds institutions accountable for ensuring the progression of women through career benchmarks and improving institutional working environments for women (12). Since 2011, funding by the National Institute for Health Research (NIHR) Biomedical Research Centre has required participation in the Athena SWAN Charter, which sharply increased membership, and participation in the Athena SWAN Charter more recently has expanded beyond the UK to institutions in Ireland and Australia.
Similar policy efforts have hit a wall in the United States, but Steitz notes with pride the work of a former undergraduate trainee in her lab, Nancy Andrews. As dean of the medical school at Duke University, Andrews made a concerted effort to hold departments accountable to higher standards for promoting and advancing women in science. Steitz comments, "Leadership all comes from the top. I learned from Beyond Bias and Barriers that there are many instances of institutions that have moved forward vastly under a particular leadership only to later backtrack." Fortunately, Andrews' legacy continues under the leadership of Mary Klotman, the current School of Medicine Dean at Duke. Notably, in the US, it is truly up to individual institutions to instate policies that ensure equitable treatment of women and minorities among their ranks.

Asked if she could use the platform afforded by her Lasker Award to promote any one change for women in science, Steitz remarked that universities and medical schools must stop fostering an atmosphere that is conducive to sexual harassment. She told the JCI, "The fact that universities keep rewarding people who've been not only been accused of, but found to have committed sexual harassment is unacceptable. We must stop those attitudes from poisoning institutions." Institutions must avoid the temptation to succumb to inertia, and actively pursue more progressive and inclusive policies.

\section{A well-deserved honor}

Joan Steitz is an exceptional scientist with an admirable and ongoing legacy in RNA biology. This year's Lasker Koshland Special Achievement Award marks not only her accomplishments in her field, but also celebrates Steitz's continuing efforts to support women in science across the spectrum of their careers.

\section{Sarah Jackson}

1. Steitz JA. Polypeptide chain initiation: nucleotide sequences of the three ribosomal binding sites in bacteriophage R17 RNA. Nature 1969;224(5223):957-964.

2. Faustino NA, Cooper TA. Pre-mRNA splicing and human disease. Genes Dev. 2003;17(4):419-437.

3. Lerner MR, Steitz JA. Antibodies to small nuclear RNAs complexed with proteins are produced by patients with systemic lupus erythematosus. Proc Natl Acad Sci U S A. 1979;76(11):5495-5499. 
4. Lerner MR, Boyle JA, Mount SM, Wolin SL, Steitz JA. Are snRNPs involved in splicing? Nature. 1980;283(5743):220-224.

5. Lewin R. Big problems faced in RNA processing. Science. 1982;216(4551):1208-1209.

6. Mount SM, Pettersson I, Hinterberger M, Karmas A, Steitz JA. The U1 small nuclear RNA-protein complex selectively binds a 5 ' splice site in vitro. Cell.1983;33(2):509-518.

7. Black DL, Chabot B, Steitz JA. U2 as well as U1 small nuclear ribonucleoproteins are involved in premessenger RNA splicing. Cell. 1985;42(3):737-750.

8. Tycowski KT, Shu MD, Steitz JA. A mam- malian gene with introns instead of exons generating stable RNA products. Nature. 1996;379(6564):464-466.

9. National Academy of Sciences (US), National Academy of Engineering (US), and Institute of Medicine. Executive Summary. Beyond Bias And Barriers: Fulfilling The Potential Of Women In Academic Science And Engineering. Washington, DC, USA: National Academies Press; 2007. https:// www.nap.edu/resource/11741/bias_and_barriers_summary.pdf. Accessed August 22, 2018

10. Doctorates awarded, by state or location, broad field of study, and sex of doctorate recipients: 2016. National Science Foundation Website. https://www.nsf.gov/statistics/2018/nsf18304/ datatables/tab06.htm. Accessed August 22, 2018.

11. U.S. residing employed doctoral scientists and engineers in 4-year educational institutions, by broad field of doctorate, sex, faculty rank, and years since doctorate: 2015. National Science Foundation Website. https://ncsesdata.nsf.gov/ doctoratework/2015/html/SDR2015_DST_18. html. Accessed August 22, 2018.

12. Ovseiko PV, Chapple A, Edmunds LD, Ziebland S. Advancing gender equality through the Athena SWAN Charter for Women in Science: an exploratory study of women's and men's perceptions. Health Res Policy Syst. 2017;15(1):12. 